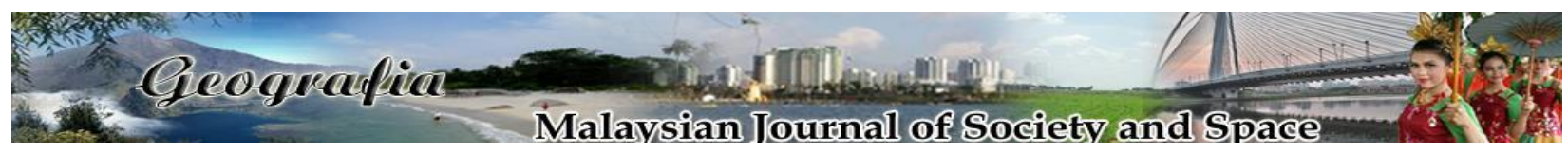

\title{
Perception and Willingness-to-Pay on conservation of lake basin under the impact of climate change - A comparison between urban and rural tropical lake
}

\author{
Zati Sharip ${ }^{1}$, Abd Ghani Awang Noor ${ }^{2}$ \\ ${ }^{1}$ Water Quality and Environment Division, National Water Research Institute of Malaysia, \\ Seri Kembangan, Malaysia \\ ${ }^{2}$ Persatuan Ekonomi Alam Sekitar Malaysia, Management and Economic Faculty, \\ Universiti Putra Malaysia, Serdang, Malaysia \\ Correspondence: Zati Sharip (email: zati@nahrim.gov.my)
}

Received: 25 December 2020; Accepted: 08 July 2021; Published: 27 August 2021

\begin{abstract}
Climatic changes are affecting the lake hydrological regime, including the associated drought and floods within the drainage basins. Assessing the value of damages to ecosystem services within the lake basin concerning the climatic changes is difficult due to the numerous ecosystem services provided by every lake basin. This study uses a Contingent Valuation Method to determine the willingness-to-pay (WTP) for lake conservation programs for addressing climate extreme impacts on urban and rural tropical lakes. Surveys using structured questionnaires were carried out around Putrajaya, the Federal Territory of Putrajaya (urban lake) and around Muda Lake, Kedah (rural lake). Respondents in both lake basins significantly differed in terms of education and income level. However, the WTP values for contribution to address climate change measures in both lakes were similar (around USD3). About $62 \%$ of respondents in both lake basins were willing to pay and contribute to climate change and conservation trust funds for preventing impacts on the lake. For Putrajaya Lake, the main reason for WTP was the need for managing lake and wetland, and their biodiversity while for Muda Lake, the main reason for WTP was the need for circumventing deterioration in the lake for future generations.
\end{abstract}

Keywords: Climate change impact, contingent valuation, ecosystem services, reservoir, willingness-to-pay

\section{Introduction}

Climate change and variability are altering hydrological regimes, such as floods or drought that affect lake water level and may lead to other ecosystem changes, subsequently alter any conservation efforts, or their estimated conservation values. Prolonged drought increased 
evaporation rates and caused declining water storage for water supply and reduced water levels in the lake. Heavier rainfall led to excess water storage that needs to be released downstream and caused the flood. All these changes in evaporation rates and rainfall amount are impacting the lake's ability to provide ecosystem services. The planned adaptation programme in Malaysia for conserving the lake basin in addressing climate issues includes protection of water catchment through gazettement of water catchment forest beside the adoption of National Water Balance Management System that covers whole river basin including lake basin (MESTECC, 2018). Integrated lake management introduced in the National Water Resources Policy in 2012 took into consideration the climate change factor in the sustainable management of water resources (MESTECC, 2018). However, the economic valuation of climate change's impact on the lake ecosystem services is not widely assessed in many developing countries nor included in the planned adaptation programme. Economic valuation on the overall climate impact on ecosystem services is increasingly performed in the developed country to determine mitigation and adaptation measures (Van der Geest et al., 2019). The economic valuation used in a recent study on the agricultural sector in one of the states in Malaysia found that $74 \%$ of farmers were willing to pay for a planned adaptation programme for addressing climate issues (Masud et al., 2015).

Increasing awareness of the ecosystem services provided by lakes has resulted in the economic valuation of lakes and wetlands being carried out worldwide to aid management and restoration efforts. Economic valuation methods being used to estimate values of different ecosystem services includes direct and indirect market valuation, non-market valuation such as contingent valuation, and group valuation (Wilson \& Carpenter, 1999; Degroot et al., 2002; National Research Council, 2005). Direct market pricing, indirect pricing (hedonic pricing, replacement cost), and existence value pricing were used to evaluate the damage cost of Lake Rotorua, New Zealand resulting from a loss of income from impaired recreation and reduced property values, as well as ecological damage costs caused by algal blooms and decline in habitat quality for aquatic fauna (Mueller \& Doole, 2016). The economic valuation used to assess costs and benefits of alternative land use and management scenarios for water quality improvement in Lake Rotorua identified options on the minimum price to the lake and land mitigation efforts (Mueller et al., 2019). Economic valuation on the value of Jagadishpur Reservoir as a Ramsar site in Nepal revealed that the option/existence value contributing the largest values followed by direct use value such as wetland products (Baral et al., 2016). Cost-benefit analysis and contingent valuation were used to evaluate the ecological compensation standard for wetland restoration projects in Lake Taihu, China (He et al., 2013).

The contingent valuation was a method, applicable when market prices were unavailable to survey and evaluate respondents' willingness to pay for ecosystem services (National Research Council, 2005). For example, Lehtoranta et al. (2013) tested the local household's willingness-topay (WTP) for regulating water level to optimum level for recreational purposes during the summertime in Lake Pielinen, Finland. Strong local interest in the WTP for lake water level regulation was shaped by high awareness of the regulation plans, the proximity of respondents to the lakeshore and owning a boat, youth factor, and higher-income factors. Similarly, Loomis et al. (2005) quantified how non-lakefront and lakefront homeowners around a residential lake rate alternative lake water levels for an irrigation reservoir (Lake Sherwood, Colorado). The increase in homeowner association fees was able to generate sufficient funds to lease the volume of water to reach the targeted higher lake level in a normal water year. In Carson and Mitchell (1993), the potential benefits of clean swimmable water bodies were equal to the costs of water pollution control, thus requiring the need to find alternative cost-effective treatment technology. Findings 
by Mulatu et al. (2018) showed that the Lake Naivasha fishing community was willing to pay a considerable amount for ecosystem services improvement in Lake Naivasha, relative to their lowincome source from fishing. Their findings illustrated how economic valuation supports fishery management by assessing the preferences of the fishing community and valuing the fishery at an ecosystem level (Mulatu et al., 2018). In Wang et al. (2016), contingent valuation provided the compensation value that is acceptable by the community to willingly live and work in polluted farms. This value was positively influenced by the family and farmland sizes, as well as their income and education levels (Wang et al., 2016).

Economic valuations on lakes such as in Malaysia were largely focused on contingent valuation method to determine the economic values in the conservation management such as in Tasek Bera (Othman \& Abdullah, 1991), Paya Indah wetland (Siew et al., 2015), Putrajaya Lake (Noordin et al., 2017) and Chini Lake (Abdullah et al., 2018). However, no valuation to our knowledge has been carried out to assess the community willingness-to-pay for a lake conservation program for addressing climate issues. The effect of climate change is increasingly impacting many developing countries including Malaysia; surface temperature in certain areas in Peninsular Malaysia showed warming trends of $2.7-4.0^{\circ} \mathrm{C} / 100$ years (Tangang et al., 2017) while basinaverage mean annual temperature increases in the range of $2.5^{\circ} \mathrm{C}-2.95^{\circ} \mathrm{C}$ (NAHRIM, 2014) that changing rainfall pattern and impacting water resources and water supply including water storage in dams. Thus, it is timely to assess the perception of the community towards these climatic changes and their impacts. This study aimed at using the Contingent Valuation Method (CVM) to assess the willingness-to-pay for addressing extreme climate impacts to tropical reservoirs. The study focused on estimating the willingness-to-pay (WTP) of the community to two man-made lakes in Malaysia; one in an urban setting and another in a rural setting. Such a study hopes to provide insight into variation in community perception in different development settings in the face of climatic effects. Public WTP is part of the Conservation Trust Funds (CTFs) that offers diverse financing mechanism to sustain conservation effort such as for protected areas (PA) management (Bladen et al., 2014). Such public WTP and CTFs, which has legal institutional structure, have been adopted in many other countries to provide sustainable financing for biodiversity conservation and protested areas (Doinjashvili et al., 2021; Bladen et al., 2014) can be extended to support the conservation of urban and rural lake basin and related sustainable development in Malaysia.

\section{Method and study area}

\section{Study sites}

This study focused on two water bodies, namely the Putrajaya Lake (urban) and Muda reservoir (rural). Currently, both lakes have different uses and attractions with no fee charged for conservation effort purposes. Putrajaya Lake has a total surface area of $4 \mathrm{~km}^{2}$ and designed for recreational purposes since its operation in 2003 (Figure 1a). The Putrajaya wetland with a total surface area of $2 \mathrm{~km}^{2}$ is the first and largest man-made wetland in Malaysia created in the year 2000 (Majizat et al., 2016). The lake and wetland system are part of the Langat River Basin and are located at the centre of the new federal administration of Malaysia, namely Putrajaya Federal Territory with a total catchment area of $51 \mathrm{~km}^{2}$. The lake is popular for its cultural services namely recreation and tourism activities and widely used for international water sport such as International 
Waterski, Canoe, and Powerboat Championship (Noordin et al., 2017; Majizat et al., 2016). The main tourism site includes the Putra Mosque with a design similar to the King Hassan Mosque in Casablanca, the Moghul-style green domes Prime Minister Office building, and various bridges (Moses, 2010). The lake is also becoming a critical freshwater habitat that houses more than 202 species of phytoplankton, 112 species of zooplankton, and 17 species of fish (Majizat et al., 2013). A total of 169 species of bird including 47 species of migratory birds, 1421 species of insects, and 17 species of mammals have been inventoried (Majizat et al., 2013). The artificial wetland of Putrajaya was acknowledged to have provided an alternative habitat for the foraging and breeding activities of different bird assemblages (Rajpar et al., 2013). The lake system was recognized as one of the operational sites for the UNESCO-IHP Ecohydrology Demonstration project since 2010 (Elfithri et al., 2014).

In contrast, Muda Lake has a total surface area of $15 \mathrm{~km}^{2}$ and was created in 1969 for irrigation of the Muda Irrigation Scheme, which is Malaysia's largest paddy irrigation system in Kedah (Lip et al., 2010). The lake is located at the most upstream of Muda River Basin within Ulu Muda Forest reserve (Figure 1b) and has a total catchment area of $984 \mathrm{~km}^{2}$. The Ulu Muda Forest is home to 15 natural saltlicks that support a diverse array of wildlife including more than 112 species of mammals; three species categorised as endangered in the International Union for the Conservation of Nature (IUCN) Red List of Threatened Species (Bashir, 2014). Muda Lake Basin is also an important habitat for many endangered species. The lake has moderate fish diversity but has become a source of income to more than 400 fishermen (Lee et al., 2013).

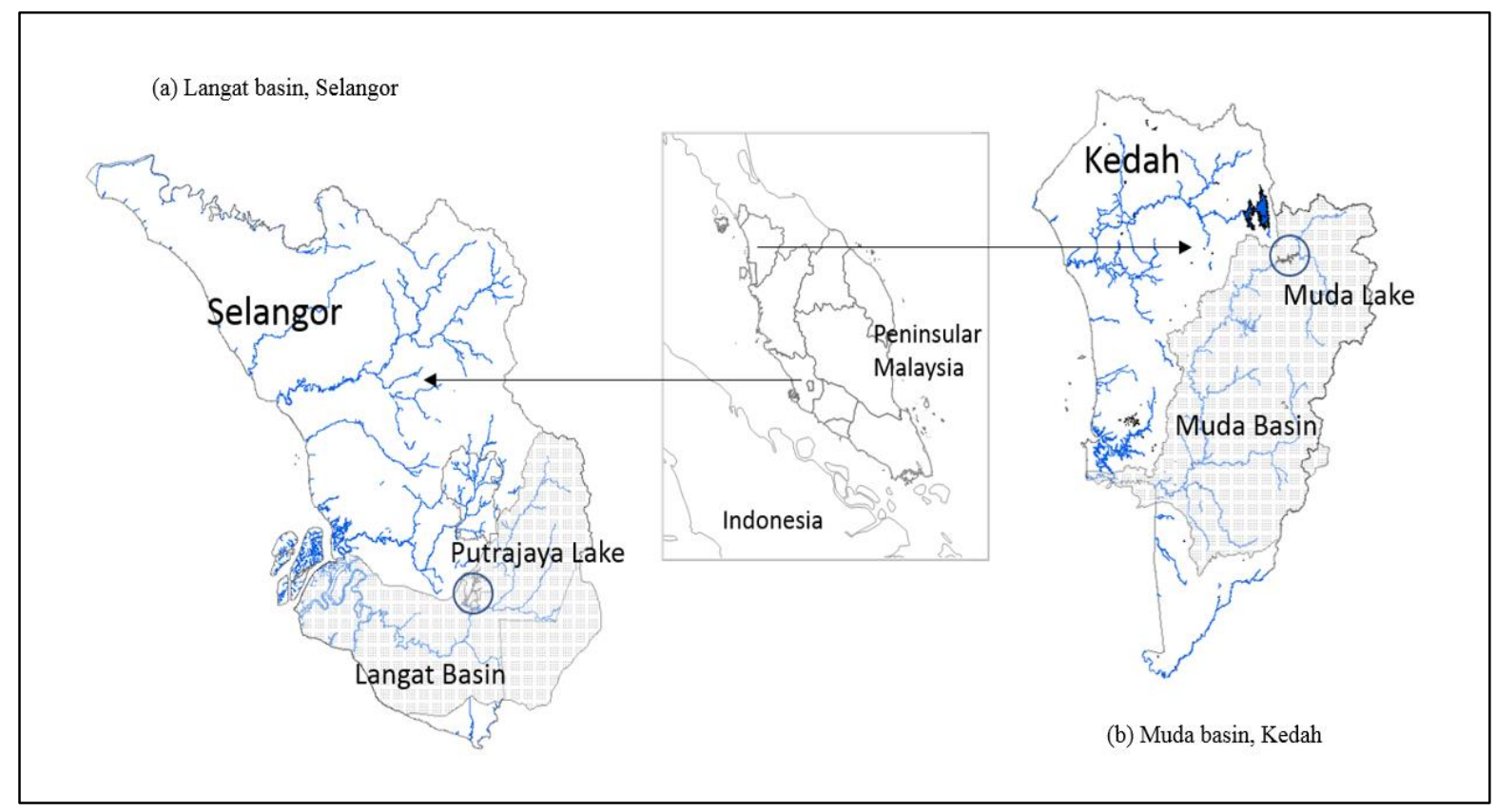

Figure 1. Study area within the river basin of the state

\section{Survey design}

A set of structured questionnaires was developed and used to collect information. The impact and extent of climatic changes namely drought and flood map were demarcated in the questionnaires. A field survey was conducted separately starting with Putrajaya Lake from August to November 2018 and Muda Lake from August to September 2018. The number of responses received from 
random face-to-face questionnaire interviews on visitors and local communities at Putrajaya and Muda was 300 and 324 adults, respectively. Local communities involved premises located within the flood zone. All valid responses from the Muda Lake survey and 298 valid responses from the Putrajaya Lake survey were used for the analysis due to missing values resulting from nonresponses to certain questions. The questionnaires for the survey process were prepared according to commonly used local bidding prices in CVM, i.e., RM1.00 (USD0.24), RM5.00 (USD1.20), RM10.00 (USD2.40), RM15.00 (USD3.60), and RM20.00 (USD4.80). To obtain answers that reflect the true maximum WTP of the respondents, a single bounded dichotomous choice is used. The respondents were asked whether they are willing or not (yes/no answer) to pay a predetermined amount of contribution to the climate change and conservation trust fund (bid price) for preventing its impacts on the lake. The bid price was randomly assigned among respondents to generate bid price variation. The respondents of the survey were selected based on a random sampling of people living and working around the study areas or visiting the lake. Flood and drought maps of extreme climate impact on Lakes were shown as reference maps in the questionnaires. Flood and drought maps were drawn based on the flood hydrograph of 100-years ARI or return period using climate change projection data findings (unpublished report: NAHRIM, 2017; Perbadanan Putrajaya, 1996). Maps were reconfirmed with the designed dam structure and the probable maximum flood level of which lake water level changes range between 0.5 to $3 \mathrm{~m}$.

\section{Economic valuation and analysis}

CVM is the preferred approach that is based on stated preference to determine the value of ecosystem services, where market prices were unavailable. The method used a social survey questionnaire by posing hypothetical scenarios that involve the description of options or alternatives and estimating the willingness of respondents to pay for such services (Degroot et al., 2002).

The mean willingness to pay (WTP) is computed based on the logit regression model following Haab and McConnel (2002) as in equation (1) below:

$$
P_{i}=P\left(Y=1 / X_{i}\right)=\frac{1}{1+e^{-\left(\alpha_{o}+\beta_{1} B i d+\sum \beta_{i} s_{i}\right)}}
$$

Where $\mathrm{P}$ is the probability to say YES, Bid is the bid price, $\mathrm{S}$ is socio-economic variables (income, age, gender, etc.).

For estimation purposes, the equation is written as follows:

$$
L_{i}=\ln \left(\frac{P_{i}}{1-p_{i}}\right)=\alpha_{o}+\beta_{1} B i d+\sum \beta_{i} S_{i}+\mu_{i}
$$

Parameters $\alpha_{0}, \beta_{1}$, and $\beta_{\mathrm{i}}$ are estimated parametrically based on the maximum likelihood method.

In this study, the mean maximum WTP or the maximum price a community is willing to pay for a conservation program for addressing climate extreme impacts are calculated using the following formula:

$$
\text { Mean maximum WTP }=\frac{1}{-\hat{\beta}_{1}}\left[\ln \left(e^{\hat{\alpha}_{0}+\sum \beta_{i} \bar{s}_{i}}+1\right)\right]
$$


The variables used in the logit model analysis are given in Table 1 which include independent variables such as gender, age, and education. Data collected were analysed using STATA software. Significant tests are carried out at the 5\% level.

Table 1. Description of variables used in logit model.

\begin{tabular}{lc}
\hline \multicolumn{1}{c}{ Variables } & Description / Category \\
\hline WTP for the stated bid & $1=$ Yes, $0-$ No \\
WTP2*for second bid & $1=$ Yes, $0-$ No \\
Independent variables & \\
Gender & $1-$ male, $0-$ female \\
Age & The age of respondent (years) \\
Education year & The number of education years of respondent \\
Race & $1-$ Malay, $0-$ others \\
Household size & The number of households \\
Category of job & $1-$ government, $0-$ others \\
Income & The monthly income of respondent $(\mathrm{RM} /$ month) \\
Marital status & $1-$ married, $0-$ others \\
Confidence in contributing the trust fund & Re-categorised likert scale: $1-$ Confidence \\
(confidence, very confidence), $0-$ others
\end{tabular}

\section{Results and discussion}

The demographic profile and descriptive statistics for the study are illustrated in Tables 2 and 3. The age of the sample in Putrajaya and Muda were between 16 to 62 and 16 to 78 respectively. Almost half of the respondents in both surveys were women. About $74 \%$ of respondents in the Putrajaya Lake survey were university or college graduates, while only $48 \%$ of respondents in the Muda Lake survey were university or college graduates and 37\% have upper secondary school education (Table 3). The main employment group for respondents in Putrajaya was the private sector followed by the government (31\%) while Muda was self-employed (36\%) and unemployed (27\%, i.e., pensioners, housewives, and students). The average income was significantly higher in Putrajaya compared to Muda ( $p<0.01$ ) (Table 2). Urban dwellers in Putrajaya are mostly government and private employees that are working in administration, commercial and private sectors; hence they have higher income.

Table 2. Description of variables used in logit model.

\begin{tabular}{lccc}
\hline Description & Putrajaya Lake & Muda Lake & $\boldsymbol{p}$-value \\
\hline Average Age (years) & 31 & 31.5 & 0.587 \\
Average Income, RM/month & 2895 & 963 & $0.000^{* *}$ \\
(USD/month) & $(696)$ & $(232)$ & \\
Average family & 4 & 5 & $0.012^{*}$ \\
Percentage of women & $47 \%$ & $46 \%$ & 0.839 \\
Percentage of resident & $18 \%$ & $8 \%$ & $0.000^{* *}$ \\
The importance of lake & $88 \%$ & $84 \%$ & 0.148 \\
Familiar with the lake & $34 \%$ & $15 \%$ & $0.000^{* *}$ \\
Lake and wetland under threat & $56 \%$ & $42 \%$ & $0.000^{* *}$ \\
Positive perception on lake conservation & $89 \%$ & $77 \%$ & $0.000^{* *}$ \\
efforts & & & \\
Populations (Adults > 20 years old) & $515,100(360,570)$ & $208,200(145,740)$ & \\
\hline
\end{tabular}


Table 3. Demographic profile of respondents.

\begin{tabular}{|c|c|c|c|c|}
\hline \multirow[t]{2}{*}{ Demographics } & \multicolumn{2}{|c|}{ Putrajaya Lake } & \multicolumn{2}{|c|}{ Muda Lake } \\
\hline & Freq & $\%$ & Freq & $\%$ \\
\hline \multicolumn{5}{|l|}{ Age (years) } \\
\hline$\leq 20$ & 54 & 17.4 & 17 & 5.9 \\
\hline $21-30$ & 139 & 44.8 & 136 & 47.2 \\
\hline $31-40$ & 56 & 18.1 & 103 & 35.8 \\
\hline $41-50$ & 25 & 8.1 & 23 & 8.0 \\
\hline $51-60$ & 24 & 7.7 & 7 & 2.4 \\
\hline$\geq 61$ & 12 & 3.9 & 2 & 0.7 \\
\hline \multicolumn{5}{|l|}{ Education } \\
\hline No formal education & 1 & 0.3 & 5 & 1.6 \\
\hline Primary & 2 & 1.6 & 18 & 5.6 \\
\hline Lower secondary & 6 & 2.05 & 24 & 7.4 \\
\hline Upper secondary & 66 & 22.7 & 119 & 36.8 \\
\hline College & 87 & 29.9 & 92 & 28.5 \\
\hline University & 129 & 44.4 & 65 & 20.1 \\
\hline \multicolumn{5}{|l|}{ Income (RM) } \\
\hline$\leq 500$ & 9 & 3.6 & 43 & 17.3 \\
\hline $501-1000$ & 21 & 8.4 & 91 & 36.7 \\
\hline $1001-1500$ & 21 & 8.4 & 47 & 18.9 \\
\hline $1501-2000$ & 39 & 15.5 & 40 & 16.1 \\
\hline $2001-2500$ & 10 & 4.0 & 9 & 3.6 \\
\hline $2501-3000$ & 40 & 15.9 & 10 & 4.0 \\
\hline$\geq 3501$ & 97 & 38.6 & 2 & 0.8 \\
\hline \multicolumn{5}{|l|}{ Category of employment } \\
\hline Government & 91 & 31.1 & 43 & 13.3 \\
\hline Private & 104 & 35.5 & 76 & 23.5 \\
\hline Self-employed & 36 & 12.3 & 116 & 35.8 \\
\hline Pensioners/Others & 62 & 21.2 & 89 & 27.5 \\
\hline
\end{tabular}

High positive responses were received in both the Putrajaya and Muda Lake survey in terms of government policy allowing lake protection using the annual budget and enhancing lake management. In terms of the lake function, the highest ranking from respondent's perception in both lakes was the lake function for future generations' use, highlighting the natural beauty and enhancing water quality (Figure 2). The lowest score in terms of lake function was as an education and research site for Muda Lake and enhancing wildlife habitat for Putrajaya Lake. Muda Lake is positioned among the rural areas and not much research has been performed out there relative to other lakes in Malaysia. A review on a lake study in Malaysia performed by Sharip et al. (2018) confirmed Muda Lake is not one of the most studied lakes. In contrast, Putrajaya Lake was identified as one of the most well-researched lakes in the country (Sharip et al., 2018). For Putrajaya, the lowest score in enhancing wildlife habitat is likely due to the origin of the lake formation where it was transformed from an oil palm plantation to an urban setting. Thus, wildlife presences were not dominant in the increasing urban ecosystem that is being created. Enhancing wildlife habitat ranked second lowest in lake function for Muda Lake. This result is worrying since wildlife habitat is important for the Ulu Muda Forest since it contains many endangered and endemic species. The reason for such lower score could probably due to low awareness among the surveyed respondents on the values of Ulu Muda wildlife that resulted from low media coverage of the importance of Ulu Muda Forest compared to other lake basin forest ecosystem such as the Belum Temenggor Reserve (Gwee et al., 2018). 


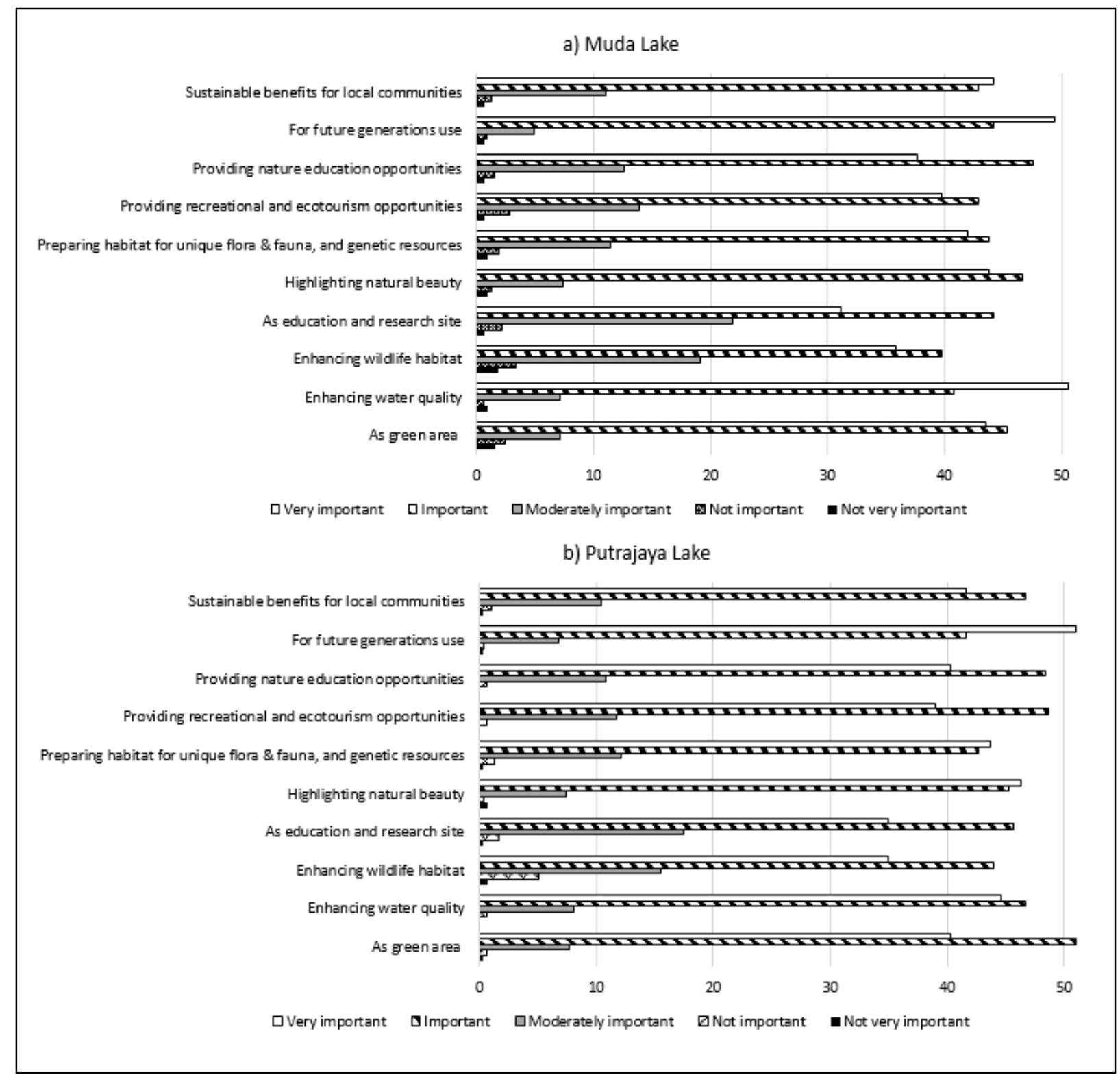

Figure 2. Respondent perception (\%) on the function of (a) Muda Lake (b) Putrajaya Lake

Three logit models were considered for the calculation of WTP based on the inclusion of independent variables in Equation 2. Model 1 is a full model that includes all variables in the equation namely income, age, gender, marital status, job category, household size, income, and confidence in contributing to the trust fund. Few variables, such as gender, marital status, and employment category, were found to be insignificant indicating that they were not influencing WTP. In Model 2, the number of independent variables was reduced to include only significant variables. After running the full model (Model 2), only the significant independent variables, namely bid and confidence were included in Model 3. Education year was also a significant variable in Muda Lake. The WTP for Muda Lake ranged between USD 2.89 to USD3.50 with a Mean maximum WTP USD 3.20 (Table 4). The WTP for Putrajaya Lake ranged between USD 2.96 to USD3.73 with a Mean maximum WTP USD 3.35. The coefficient on education for Muda Lake is positive and significant, suggesting that WTP increases with the number of education 
years. WTP does not appear to be sensitive for education year for Putrajaya Lake probably due to small gaps in education year as the most respondent has tertiary education.

Table 4. The results of logit models for Muda and Putrajaya Lake

\begin{tabular}{|c|c|c|c|c|c|c|}
\hline \multirow[b]{2}{*}{ Variable } & \multicolumn{2}{|c|}{ Model 1} & \multicolumn{2}{|c|}{ Model 2} & \multicolumn{2}{|c|}{ Model 3} \\
\hline & Coefficient & SE & Coefficient & SE & Coefficient & SE \\
\hline \multicolumn{7}{|l|}{ Muda Lake } \\
\hline Constant & 2.2782 & 1.713 & -0.8538 & 0.6112 & -0.6218 & 0.5375 \\
\hline Bid & $-0.2478^{*}$ & 0.042 & -0.2178 & 0.0312 & -0.2322 & 0.0288 \\
\hline Income & 0.0002 & 0.0002 & -0.0001 & 0.0002 & - & - \\
\hline Gender & -0.3829 & 0.4599 & - & - & - & - \\
\hline Age & -0.0253 & 0.026 & - & - & - & - \\
\hline Marital status & 0.3340 & 0.615 & - & - & - & - \\
\hline Education & 0.1027 & 0.082 & $0.2001 *$ & 0.0536 & $0.1669^{*}$ & 0.0455 \\
\hline Household income & -0.1475 & 0.118 & - & - & - & - \\
\hline Employment category & -0.1652 & 0.468 & - & - & - & - \\
\hline Confidence & $-2.0073^{*}$ & 0.516 & $2.3364 *$ & 0.3930 & $2.5576^{*}$ & 0.3686 \\
\hline $\mathrm{R}^{2}$ & 0.370 & & 0.321 & & 0.334 & \\
\hline Log likelihood & -66.843 & & -112.46 & & -143.17 & \\
\hline Model $X^{2}$ value & 78.53 & & 106.02 & & 143.85 & \\
\hline $\mathrm{n}$ & 163 & & 248 & & 323 & \\
\hline $\begin{array}{l}\text { Mean WTP in USD (RM) } \\
95 \% \text { confidence interval }\end{array}$ & $\begin{array}{c}3.36(13.99) \\
2.89-3.83\end{array}$ & & $\begin{array}{c}3.29(12.69) \\
2.91-3.66\end{array}$ & & $\begin{array}{c}3.19(13.28) \\
2.89-3.50\end{array}$ & \\
\hline \multicolumn{7}{|l|}{ Putrajaya lake } \\
\hline Constant & 1.582 & 1.4266 & 1.409 & 0.7754 & 1.623 & 0.3782 \\
\hline Bid & $-0.183^{*}$ & 0.0273 & $-0.168^{*}$ & 0.0256 & $-0.182 *$ & 0.0235 \\
\hline Income & 0.00002 & 0.0001 & -0.00006 & 0.0001 & - & - \\
\hline Gender & -0.290 & 0.3297 & - & - & - & - \\
\hline Age & $0.055^{*}$ & 0.0266 & 0.030 & 0.0216 & - & - \\
\hline Marital status & 0.610 & 0.4501 & - & - & - & - \\
\hline Education & -0.028 & 0.0628 & - & - & - & - \\
\hline Household income & $-0.171 *$ & 0.0782 & $-0.144 *$ & 0.0745 & - & - \\
\hline Employment category & -0.616 & 0.3905 & - & - & - & - \\
\hline Confidence & $0.853^{*}$ & 0.4317 & $0.923^{*}$ & 0.4202 & $1.127 *$ & 0.3450 \\
\hline $\mathrm{R}^{2}$ & 0.232 & & 0.209 & & 0.220 & \\
\hline Log likelihood & -117.51 & & -122.69 & & -153.84 & \\
\hline Model $\mathrm{X}^{2}$ value & 71.17 & & 64.99 & & 86.86 & \\
\hline $\mathrm{n}$ & 226 & & 230 & & 298 & \\
\hline Mean WTP in USD (RM) & $3.16(13.14)$ & & $3.17(13.19)$ & & $3.34(13.92)$ & \\
\hline $95 \%$ confidence interval & $2.73-3.59$ & & $2.71-3.63$ & & $2.96-3.73$ & \\
\hline
\end{tabular}

Note: * Significant at the 5\% level; RM=0.24 USD, SE - standard errors

For Putrajaya Lake, the mean WTP per person was USD3.35 (Table 4). Among the main reasons for willingness to pay for Putrajaya Lake is for managing lake and wetland, and its 
biodiversity in Putrajaya Lake contributing about 30\% of response followed by circumventing deterioration in ensuring the Lake can be used for future generations contributing about $25 \%$ of responses. This WTP value is slightly lower than the WTP value found in an earlier study on the conservation of Putrajaya Lake (Noordin et al., 2018). This low value is possibly due to different respondents surveyed. Respondents in the earlier study were largely tourists and recreational users. In this study, respondents include communities living and working in the areas. The total value of Putrajaya Lake based on the adult population and under the present net value of $8 \%$ was USD2.35 million (Putrajaya Lake catchment) or about USD15.1 million (Putrajaya and downstream). This study showed that respondents perceived that the management of Putrajaya Lake and wetland and its biodiversity as the main factor driving the motivation to pay (Figure 3). Since the lake is a manmade lake created for recreation purposes, its management is crucial for ensuring that the water quality remains at its highest standard for primary and secondary body contact (Majizat et al., 2016). Respondents' positive response indicates that the management of Putrajaya Lake is important.

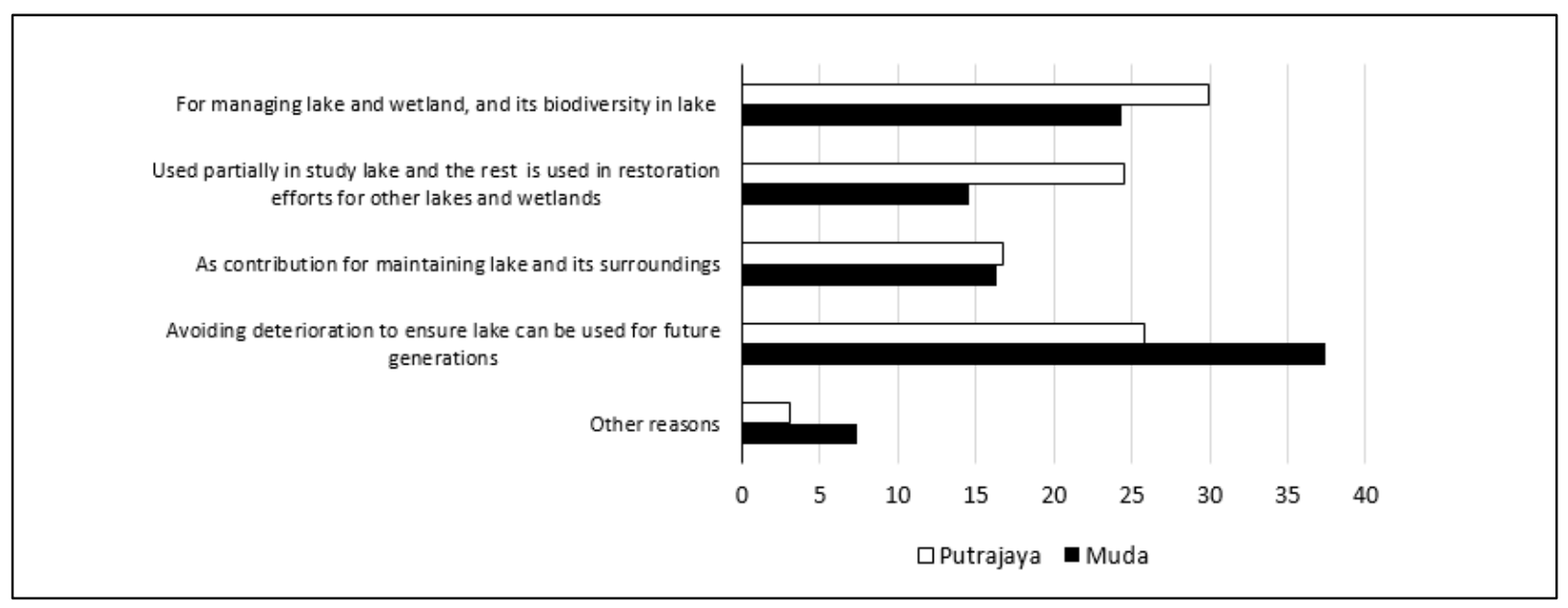

Figure 3. Motivation factors for WTP (\%) in (a) Muda Lake (b) Putrajaya Lake

For Muda Lake, the mean WTP per person was USD3.20 (Table 4). Among the main reasons for willingness to pay for Muda Lake is for avoiding deterioration in the lake so that it can be used for future generations contributing about $37 \%$ of response followed by the need for managing lake and wetland, and its biodiversity contributing about $24 \%$ of the response. The total value of Muda Lake based on the number of the adult population and under the present net value of $8 \%$ was about USD5.816 million. A higher WTP value will be expected if the total population downstream of the areas were included. The main factor driving the motivation to pay was for avoiding further deterioration of Muda Lake for future generations.

The WTP found in this study is much higher compared to WTP for conservation of Tasik Chini and Paya Indah Wetland, Malaysia. The WTP for entrance using logit model to Tasik Chini was USD2.14 per entrance contributing to a value of about USD39,022 (Abdullah et al., 2018) while in Paya Indah wetland was USD1.71 per entrance fee per person contributing to a value of about USD151,626.90 in 2012 (Siew et al., 2015). Tasik Chini and Paya Indah Wetland are two wetlands of importance in Malaysia that are in rural areas. Public willingness to pay for conservation of Tasik Chini Biosphere reserve increased with the improvement of four attributes 
namely lotus cover, lotus varieties, diversity of fish, and aesthetics values (Abdullah et al., 2018). Higher WTP recorded in this study indicates higher regard for the local communities in the area for conservation of both lake basins. In an earlier study, the WTP for conservation of Putrajaya Lake alone was reported at USD3.51 contributing to a total value of more than USD240 million when considering the total Klang Valley population (Noordin et al., 2017, 2018). WTP found in this study is slightly lower than WTP in a previous study that focuses on the management of lakes and wetlands. Lower values would probably due to lower awareness of climate change impact among the respondents. Putrajaya Lake is one of the most well-designed and managed lake basins in the country also has considered various measures in the design of the dam to address hydrological variability. Awareness of climate change impacts on Muda Lake management was also high possibly due to the importance of the dam in irrigating the country's largest paddy irrigation scheme. Extreme prolonged droughts had occurred in the area impacting the doublecropping planting and increasing awareness and preparedness among the agencies and residents towards extreme events and climate change (Lip, 2010; ICID, 2017).

A total of $38.2 \%$ of participants in the Muda survey and $37.6 \%$ of participants in the Putrajaya survey were not willing to pay for the contribution of climate change and conservation trust funds (Table 5). Most of the participants $(>50 \%)$ were unwilling to pay because they perceive that management and maintenance costs should be borne by the government. About $15 \%$ of the population in the Muda survey have low income to afford to contribute to the fund while another $15 \%$ of the population are willing to pay different amounts. While in the Putrajaya Lake survey, about $18 \%$ of the population are willing to pay different amounts of climate change funds while another $16 \%$ of the population are willing to pay in other different ways.

Table 5. The reason for not willing to pay (percentage).

\begin{tabular}{lcc}
\hline Reason & Putrajaya Lake & Muda Lake \\
\hline Not afford to pay & 7 & 15 \\
Willing to pay but not the stated amount & 18 & 15 \\
Willing to pay the stated amount but in different ways & 16 & 9 \\
Management and maintenance costs should be borne by the government & 51 & 57 \\
Others & 7 & 4 \\
\hline
\end{tabular}

In this study, no correlations were observed between income, gender, marital status, and job category parameters, and WTP in both surveys. People's willingness to pay was not related to their income levels. The year of education was significantly correlated to WTP in the final logit model. The long years in the education of the participants, the higher the willingness to contribute to conservation and protection. This is consistent with findings by Langford et al. (1998) that people with higher education levels can understand the need for conserving and protecting lake environmental resources. Age was positively correlated with WTP while bid price and household size were negatively correlated with WTP in the first model of the Putrajaya survey but these parameters were not correlated in the final model. The older people in the urban areas are interested in contributing possibly for future generations. Factors influencing people's willingness to pay (WTP) for protecting an artificial lake on Plastira Lake in Greece were influenced mainly by respondent origin (residents or recreational users) and demographic characteristics or their opinion of the lake's attributes (Halkos and Matsiori, 2016). This finding indicates that local communities in both lake basins were willing to pay and contribute to a conservation trust fund for preventing impacts of climate change despite their age and income differences. As climate change impact is 
inevitable, the establishment of such environmental-related funds will enable necessary preparation for the conservation of these lakes against climate change-induced impacts. Establishing such public funds has also been recognized in the 2030 Agenda for Sustainable Development Goals as part of a mechanism to promote sustainable financing to manage and protect lake basin and their multiple ecosystem services (Doinjashvili et al., 2014).

\section{Conclusion}

In conclusion, economic valuation using CVM at Putrajaya Lake and Muda Lake showed that more than $60 \%$ of participants surveyed were willing to pay for the climate change and conservation trust fund for preventing climate change impacts on the study lakes. Education was the only significant variable correlated to WTP. Regardless of different income level and age of respondents, the main reason for WTP in Putrajaya Lake was the need for managing the urban lake including the wetland, and the associated biodiversity for its main ecosystem services namely recreation while for Muda Lake was for dodging deterioration of the lake environment for future generations. The WTP values recorded in Muda Lake and Putrajaya Lake were USD3.20 and USD3.35, respectively contributing to the total value of about RM5.8 million and USD15.1 million respectively. The findings from this study can be used to support the climate change adaptation planning as well as future basin management plans to justify the establishment of such conservation trust funds to enhance funding mechanism considering imminent climatic changes.

\section{Acknowledgement}

This research was financially supported by the Ministry of Environment and Water through program Extended Study on the Impacts of Climate Change on Water Resources (vote No. P23170000190001). We thank Perbadanan Putrajaya and MADA for allowing us to conduct this study in the area. Special thanks are accorded to various individuals for their assistance in data collection and technical contribution, for their financial and management support.

\section{References}

Abdullah, M., Mamat, M. P., Emang, D., Hussain, F. N. T., \& Fui, L. H. (2018). Economic valuation of Tasik Chini Biosphere Reserve, Pahang, Malaysia. ASM Science Journal, 11, 74-78.

Baral, S, Basnyat, B., Khanal, R., \& Gauli, K. (2016). A Total Economic Valuation of Wetland Ecosystem Services: An evidence from Jagadishpur Ramsar Site, Nepal. The Scientific World Journal, 2016, 2605609.

Bashir, A. Z. (2014). Wildlife Diversity Near Natural Saltlicks in the Ulu Muda Forest Reserve, Petaling Jaya, WWF Malaysia.

Bladon, A., Mohammed, E. Y., \& Milner-Gulland, E. (2014). Review of conservation trust funds for sustainable marine resources management: conditions for success. London, International Institute for Environment and Development. 
Carson, R. T., \& Mitchell, R. C. (1993). The value of clean water: The public's willingness to pay for boatable, fishable, and swimmable quality water. Water Resources Research, 29, 24452454.

De Groot, R. S., Wilson, M. A., Boumans, R. M. J. A. (2002). Typology for the classification, description and valuation of ecosystem functions, goods and service. Ecological Economics, 41, 393-408.

Doinjashvili, P., Méral, P., \& Andriamahefazafy, F. (2021). Sustaining protected areas through conservation trust funds: a review. International Journal of Sustainable Development \& World Ecology, 28(3), 193-202.

Elfithri, R., Mokhtar, M.B. \& Majizat, A. (2014). Ecohydrology approach for management of lakes and wetlands in Putrajaya, Malaysia. In. Sutapa, I.D.A., Zhaou, D., Kobayashi, K., Hidayat, Subehi, L. Api, P \& Rustini, H.A. (Eds.), Proceeding International Conference on Ecohydrology (ICE) in Conjunction with the 22nd Meeting of UNESCO IHP Regional Steering Committee for South Asia and Pacific (pp. 459-467). Bogor, UNESCO Asia Pacific Centre for Ecohydrology \& Research Center for Limnology.

Gwee, S. L., Tan, A. K. G. \& Narayanan, S. (2018). Sustainable Tourism and Forest Conservation: The Case of the Belum-Temengor Rainforest Complex in Perak, Malaysia. Journal of Sustainable Forestry, 38, 327-342.

Haab, T., \& McConnell, K. E. (2002). Valuing Environmental and Natural Resources. Cheltenham, Edward Elgar Publishing.

Halkos, G., \& Matsiori, S. (2016). Determining public attitudes and willingness-to-pay for artificial lakes protection. Water Resources and Economic, 15, 15-27.

He, J., Ai, J., Zhu, X., \& Sun, X. (2015). Ecological Compensation Standards of Wetland Restoration Projects. Polish Journal of Environmental Studies, 24, 2421-2432.

ICID. (2017). Institutional Reforms in Irrigation Sector for Sustainable Agriculture Water Management, including water users Association - A specific case of Muda Agricultural Development Authority (MADA) In: 23rd International Congress on Irrigation and Drainage: Symposium on 'Global Review of Institutional Reforms in Irrigation Sector for Sustainable Agriculture Water Management, including Water Users' Association, Mexico City, ICID.

Langford, I. H., Kontogianni, A., Skourtos, M. S., Georgiou, S., \& Bateman, I.J. (1998). Multivariate mixed models for open-ended contingent valuation data: willingness to pay for conservation of monk seals. Environmental Resource Economics, 12, 443-456.

Lee, P. K. Y., Shah, A. S. R. M., \& Khaironizam, M. Z. (2013). Assessment of the Freshwater Fisheries in Ulu Muda, Kedah. Petaling Jaya, WWF-Malaysia.

Lehtoranta, V., Seppala, E., \& Kosenius, A-K. (2013). Willingness to pay for water level regulation in Lake Pielinen, Finland AU. Journal of Environmental Economic Policy, 2, 148-163.

Lip, H. T. (2010). Tasik Pedu and Muda, Kedah, Lake Brief. In: Managing lakes and their basins for sustainable use in Malaysia (Lake Briefs Report Series 1) (pp. 125-137). Kuala Lumpur, Akademi Sains Malaysia.

Loomis, J., Smith, A., \& Huszar, P. (2005). Estimating the economic benefits of maintaining residential lake levels at an irrigation reservoir: A contingent valuation study. Water Resources Research, 41, W08405. 
Masud, M. M., Junsheng, H., Akhtar, R., Al-Amin, A. Q., \& Kari, F. (2015). Estimating farmers' willingness to pay for climate change adaptation: the case of the Malaysian agricultural sector. Environmental Monitoring Assessment, 187, 38.

Majizat, A., Ahmad, B., Noordin, N., \& Sharip, Z. (2016). Adopting an integrated catchmentbased management approach for Putrajaya Lake and Wetlands. International Journal of Water, 10, 343-358.

Majizat, A., Abdullah, M., Ahmad, N., Noordin, N., \& Rahman, N. A. (2013). Biodiversity in an urban ecosystem: Putrajaya Lake and Wetland. Putrajaya, Perbadanan Putrajaya.

Moser, S. (2010). Putrajaya: Malaysia's new federal administrative capital. Cities, 27, 285-297.

MESTECC. (2018). Malaysia Third National Communication and Second Biennial Update Report to the UNFCC. Putrajaya, MESTECC.

Mulatu, D. W., van Oel, P. R., Odongo, V., \& van der Veen, A. (2018). Fishing community preferences and willingness to pay for alternative developments of ecosystem-based fisheries management (EBFM) for Lake Naivasha, Kenya. Lakes \& Reservoirs: Research \& Management, 23, 190-203.

Mueller, H., Hamilton, D., \& Doole, G. (2016). Evaluating services and damage costs of degradation of a major lake ecosystem. Ecosystem Services, 22, 370-380.

Mueller, H., Hamilton, D., Doole, G., Abell, J., \& McBride, C. (2019). Economic and ecosystem costs and benefits of alternative land use and management scenarios in the Lake Rotorua, New Zealand, catchment. Global Environment Change, 54, 102-112.

National Research Council. (2005). Valuing ecosystem services: toward better environmental decision-making. Washington DC, National Academies Press.

NAHRIM. (2014). Extension study of the impacts of climate change on the hydrologic regime and water resources of Peninsular Malaysia. Seri Kembangan, National Hydraulic Research Institute of Malaysia.

NAHRIM. (2017). Region Specific Flood Damage Curve on Consequential Flood Inundations in a Changing Climate Environment. Seri Kembangan, National Hydraulic Research Institute of Malaysia.

Noordin, N., Majizat, A., Sharip, Z., \& Sapian. Z. (2017). Ecohydrology management of lake and wetland in Putrajaya urban ecosystem. In. Maghfiroh, M., Dianto, A., Jasalesmana, T., Melati, I., Samir, O., Kurniawan, R.L. (Eds), Lake Ecosystem Health and Its Resilience: Diversity and Risks of Extinction, Proceedings of 16th World Lake Conference (pp. 375387). Bali, Lembaga Ilmu Pengetahuan Indonesia.

Noordin, N., Sharip, Z., Mahfidz, N. A. A., Majizat, A., \& Ghani, A. N. A. (2018). Ecosystem Services Valuation for urban lake and wetland - a case of Putrajaya. In: Proceedings of 17th World Lake Conference (pp. 855-857). Ibaraki, Japan.

Othman, M. S., \& Abdullah, N. M. R. (1991). Economic valuation of wetland plant, animal, and fish species of Tasek Bera and residents' perceptions on development and conservation. Kuala Lumpur, Asian Wetland Bureau.

Perbadanan Putrajaya. (1996). Drainage Master Plan Study Report for Putrajaya development Project. Kuala Lumpur: Perbadanan Putrajaya.

Rajpar M. N., \& Zakaria, M. (2013). Assessing an Artificial Wetland in Putrajaya, Malaysia, as an Alternate Habitat for Waterbirds. Waterbirds, 36, 482-493.

Sharip Z., Suratman, S., \& Shaaban, A. (2016). A national research and development blueprint for sustainable lake basin management in Malaysia. Lakes \& Reservoirs: Research \& Management, 21, 269-283. 
Siew, M. K., Yacob, M. R., Radam, A., Adamu, A., \& Alias, E. F. (2015). Estimating willingness to pay for wetland conservation: a contingent valuation study of Paya Indah Wetland, Selangor Malaysia. Procedia Environmental Science, 30, 268-272.

Tangang, F. T., Juneng, L., \& Ahmad, S. (2007). Trend and interannual variability of temperature in Malaysia: 1961-2002. Theoretical and Applied Climatology, 89(3-4), 127-141.

van der Geest, K., de Sherbinin, A., Kienberger, S., Zommers, Z., Sitati, A., Roberts, E., \& James, R. (2019). The impacts of climate change on ecosystem services and resulting losses and damages to people and society. In. Mechler, R., Bouwer, L.M., Schinko, Th., Surminski, S., Linnerooth-Bayer, J. (Eds.), Loss and Damage from Climate Change (pp. 221-236). Cham, Springer.

Wang, X, Zhang, Y., Huang, Z., Hong, M., Chen, X., Wang, S., Feng, Q., \& Meng, X. (2016). Assessing willingness to accept compensation for polluted farmlands: a contingent valuation method case study in northwest China. Environmental Earth Science, 75, 179.

Wilson, M. A., \& Carpenter, S. R. (1999). Economic valuation of freshwater ecosystem services in the United States: 1971-1997. Ecological Application, 9, 772-783. 